\title{
Międzyrzecki Rejon Umocniony - w oczekiwaniu na adaptacje i modernizacje
}

\author{
Bartosz Michalak \\ Zakład Budownictwa Ogólnego, Instytut Budownictwa, \\ Wydział Budownictwa, Architektury i Inżynierii Środowiska, Uniwersytet Zielonogórski, \\ e-mail: b.michalak@ib.uz.zgora.pl
}

Streszczenie: Pomiędzy Wrocławiem a Krosnem Odrzańskim, w latach 1928-1944, zbudowano około 650 żelbetowych schronów bojowych i biernych. Na odcinku ok. $250 \mathrm{~km}$ wzniesiono zarówno niewielkie obiekty przeznaczone dla dwóch, trzech osób jak i obiekty mieszczące całe podziemne koszary. Ponadto stawiano betonowe zapory przeciwczołgowe, budowano tamy, zapory, przeprawy mostowe i inne betonowe konstrukcje. Ważnym odcinkiem tych umocnień wschodnich granic Niemiec był Międzyrzecki Rejon Umocniony (MRU), obecnie w województwie lubuskim. Od lat 70. XX w. obiekty te nie pełnią pierwotnych funkcji. Jest to jednak nadal jeden z największych systemów obronnych na świecie. Długość podziemnych korytarzy wynosi ponad $30 \mathrm{~km}$. Przyroda z czasem wykorzystała te pomieszczenia jako naturalne siedlisko dla dziesiątków tysięcy nietoperzy. Niestety, wciąż nie ma konkretnego planu zmiany ich funkcji. Wykorzystanie tych budowli dla współczesnych celów będzie wymagało ogromnych środków finansowych ale przede wszystkim interesujących idei i odważnych projektów.

W artykule przedstawiono historię oraz opis kompleksu a także propozycje adaptacji schronów na nowe cele. Istnieje kilka koncepcji a realizacja tych planów byłaby cenną inicjatywą związaną z ochroną tego wyjątkowego obszaru i znajdujących się na nim obiektów inżynierskich.

Słowa kluczowe: fortyfikacje, bunkry, Brama Lubuska, muzeum sztuki wojennej, Pniewo.

\section{Wprowadzenie}

Europa w ciągu ostatnich stuleci wielokrotnie doświadczała konfliktów zbrojnych, które różniły się zasięgiem geograficznym i skalą działań militarnych. Ze względu na swoje położenie geopolityczne, kraje znajdujące się na terenie Europy Środkowej brały udział w większości z nich. W związku z tym na ich obszarze konieczna była budowa systemów umocnień i fortyfikacji, które miały na celu obronę wciąż zmieniających się granic. Skala tego zjawiska osiągnęła znaczące rozmiary po zakończeniu I wojny światowej w roku 1918. Francja rozpoczęła w tym czasie budowę Linii Maginota na granicy z Niemcami, Polska po odzyskaniu niepodległości rozpoczęła budowę umocnień na granicy wschodniej z ZSRR, a Niemcy na mocy Traktatu Wersalskiego teoretycznie zostały pozbawione możliwości rozbudowy swoich systemów obronnych. Teoretycznie, ponieważ brak właściwej kontroli nad poczynaniami Niemców, doprowadził do tego, że w rzeczywistości już w latach 20. XX w. rozpoczęli oni prace nad systemem umocnień na terenie Prus Wschodnich a w roku 1928 ruszyły pierwsze, prowadzone w tajemnicy, prace nad budową fortyfikacji wzdłuż wytyczonej 
dziesięć lat wcześniej granicy z Polską. Niemieccy stratedzy uznali, że najlepszym ze względów geograficznych miejscem do budowy linii umocnień będzie tak zwana Brama Lubuska. Jest to teren rozciągający się pomiędzy rzekami Wartą i Odrą, na wysokości od Cigacic koło Zielonej Góry, do Gorzowa Wielkopolskiego (rys. 1). W znaczeniu militarnym położony jest on na strategicznym obszarze, nazywanym główną drogą wojny (Paryż-Berlin-Warszawa-Moskwa) i stanowi najkrótszą drogę ze wschodu do stolicy Niemiec - Berlina. Od położenia w łuku rzek Warty i Odry powstała nazwa planowanego systemu umocnień Festungfront Oder-Warthe-Bogen (Front umocniony na Łuku Odry-Warty). Docelowo całość planowanego systemu umocnień wzdłuż wschodniej granicy Niemiec miała rozciągać się od Pomorza na północy aż do Wrocławia na południu (Obszar Warowny Śląsk). Brama Lubuska znajdowała się w centralnej części systemu [1].

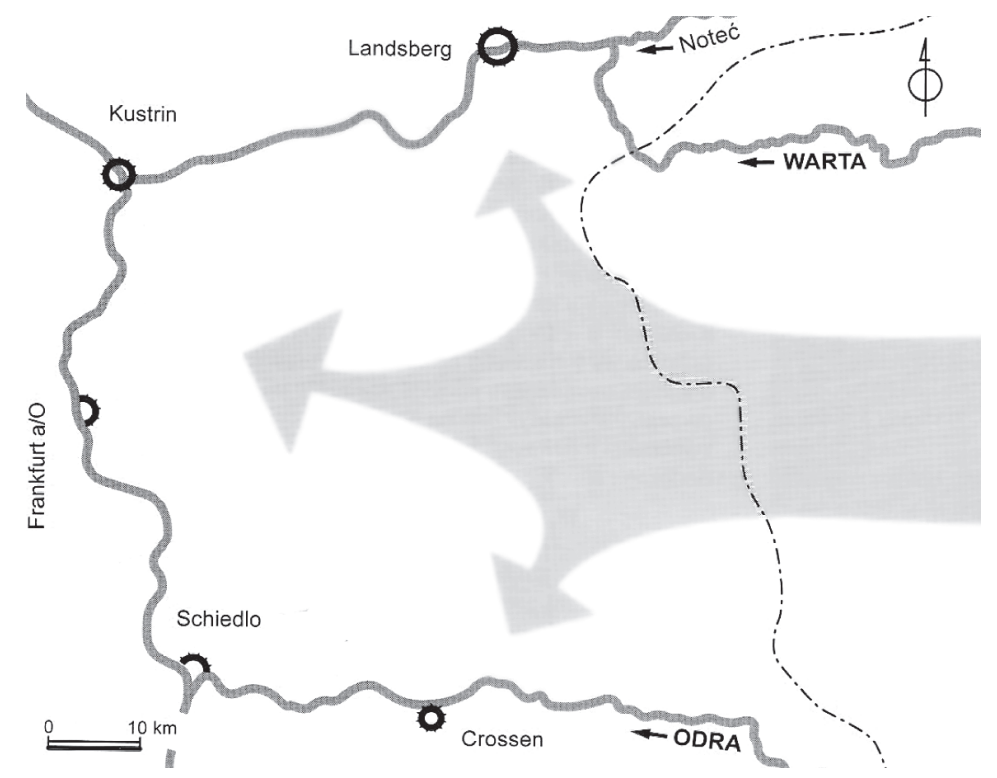

Rys. 1. Brama Lubuska pomiędzy rzekami Odrą i Wartą z widocznym kierunkiem ataku ze wschodu [1]

\section{Koncepcja i budowa fortyfikacji - lata 1928-1945}

W roku 1928 rozpoczęto w tajemnicy prace teoretyczne i projektowe nad przyszłą inwestycją. Po objęciu władzy przez Adolfa Hitlera w roku 1933 prace nad budową fortyfikacji zostały mocno przyspieszone. Opracowane koncepcje były rozwinięciem niemieckich planów umocnień z początków XIX w. oraz unowocześnieniem rozwiązań zastosowanych przy budowie francuskiej Linii Maginota (rys. 2). W roku 1935 plac budowy wizytowało całe naczelne dowództwo armii wraz z Adolfem Hitlerem, który był zadowolony z postępu prac i dalszych perspektyw. Oszacowano wtedy, że cała planowana linia umocnień będzie zakończona około roku 1950. Po tej wizycie budowa otrzymała status priorytetowy, który utrzymała do roku 1938. W tym czasie Führer ocenił szybkość realizacji inwestycji jako niewystarczającą i nakazał zakończenie prac. Dalsza budowa została wstrzymana, pozwolono jedynie dokończyć już rozpoczęte obiekty, co z przerwami trwało do roku 1944. 


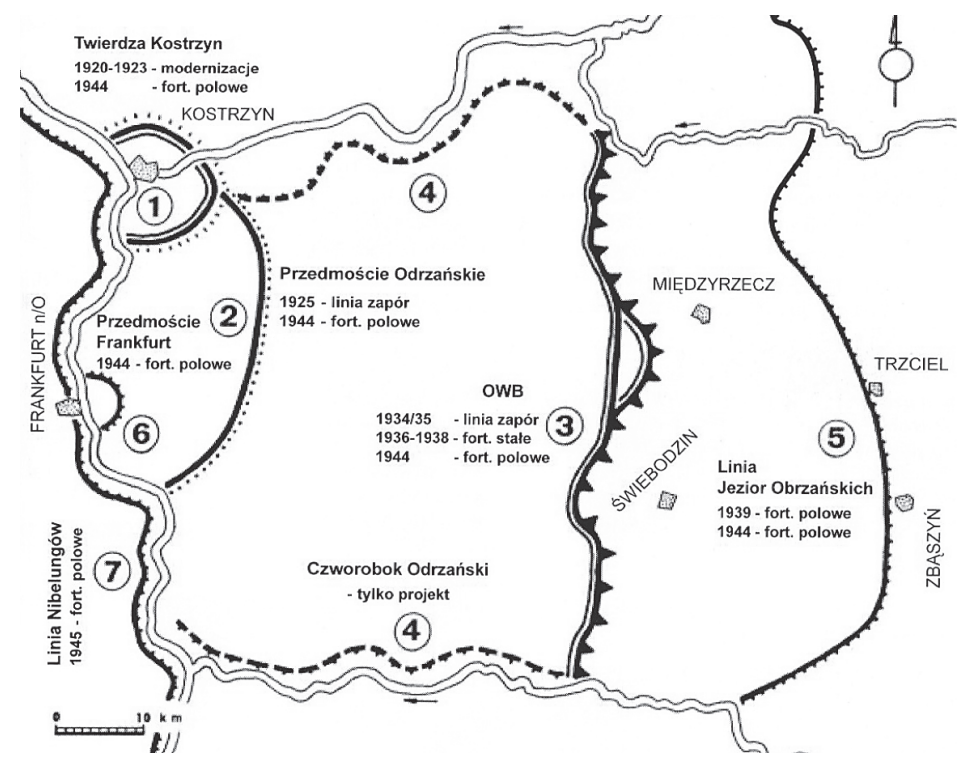

Rys. 2. Plan frontu ufortyfikowanego Festungfront Oder-Warthe-Bogen (planu nie zrealizowano w całości) [1]

Podczas budowy systemu schronów i korytarzy podziemnych wykonano także linię kolejową o długości około $80 \mathrm{~km}$ z bocznicami i magazynami materiałów budowlanych oraz system utwardzonych dróg dla pojazdów kołowych [2]. System obronny, oprócz schronów, baterii artylerii i korytarzy podziemnych składał się także z budowli hydrotechnicznych (zapór spiętrzających), które pozwalały na zalanie wodą wybranych obszarów oraz zapór przeciwpancernych, nazywanych zębami smoka (rys. 3) [1].

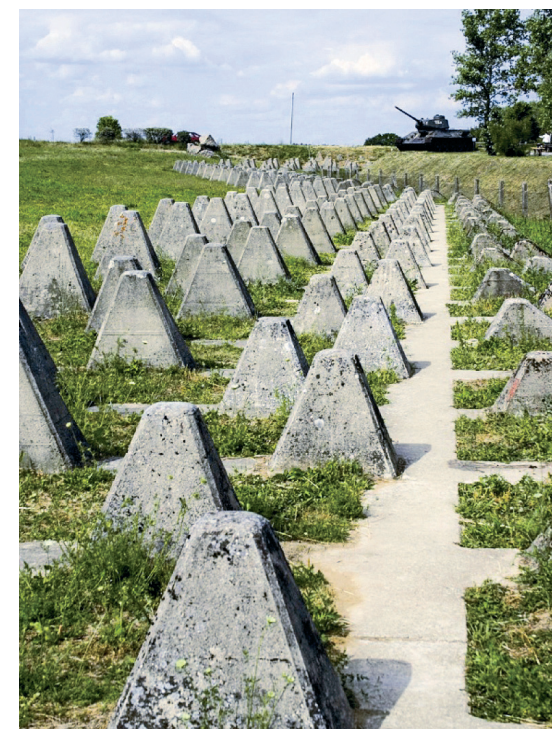

Rys. 3. Zapora przeciwpancerna „zęby smoka” w rejonie Międzyrzecza 
Schrony nazywano Panzerwerkami (rys. 4). Były one zróżnicowane pod względem wielkości, przeznaczenia oraz opancerzenia (klasy od A do C). Głównym materiałem służącym do budowy fortyfikacji był zbrojony beton oraz stal. Grubość żelbetowych ścian i stropów w najbardziej opancerzonych obiektach (klasy A) dochodziła do 3,5 m, a grubość stalowych kopuł osłaniających stanowiska ogniowe do 0,42 m. Najczęściej budowano jednak obiekty klasy B, o grubości ścian 2,5 m i opancerzeni stalowym o grubości $0,25 \mathrm{~m}$. Do budowy niższych, podziemnych kondygnacji używano również cegły klinkierowej (rys. 5). Przeznaczano je na cele wypoczynkowe i socjalne.

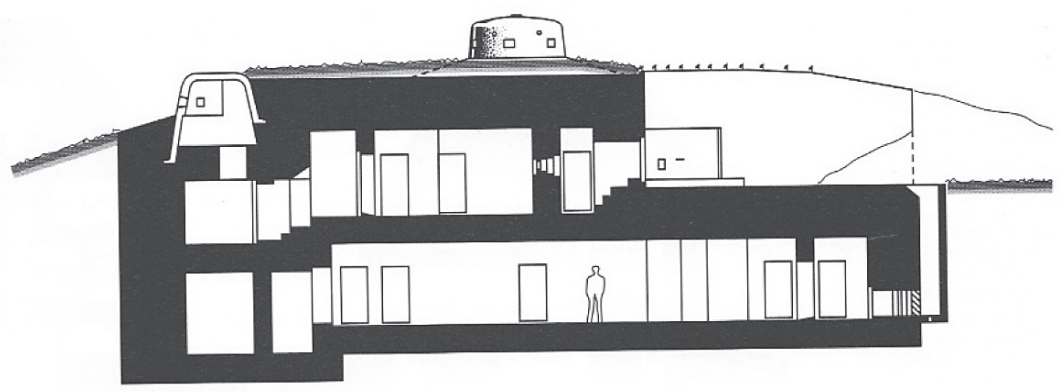

Rys. 4. Przekrój przykładowego schronu Panzerwerk [1]

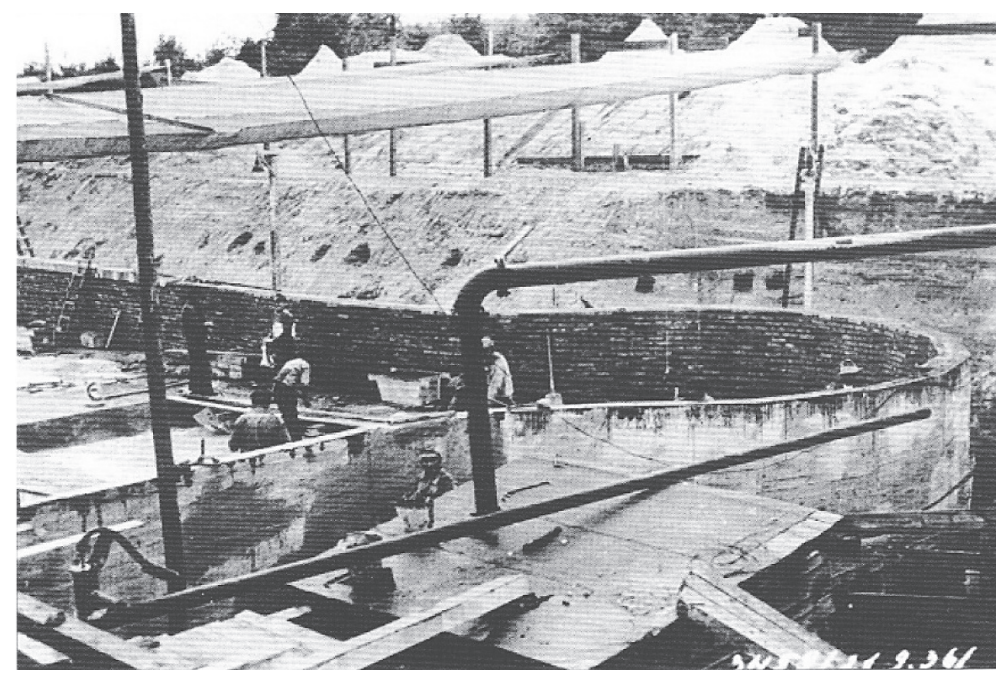

Rys. 5. Budowa schronu Panzerwerk - rok 1936 [1]

Schrony połączone były systemem podziemnych korytarzy (rys. 6 i 7), których łączna długość wynosi około 30 km (zrealizowana została jedynie część pierwotnych planów). 


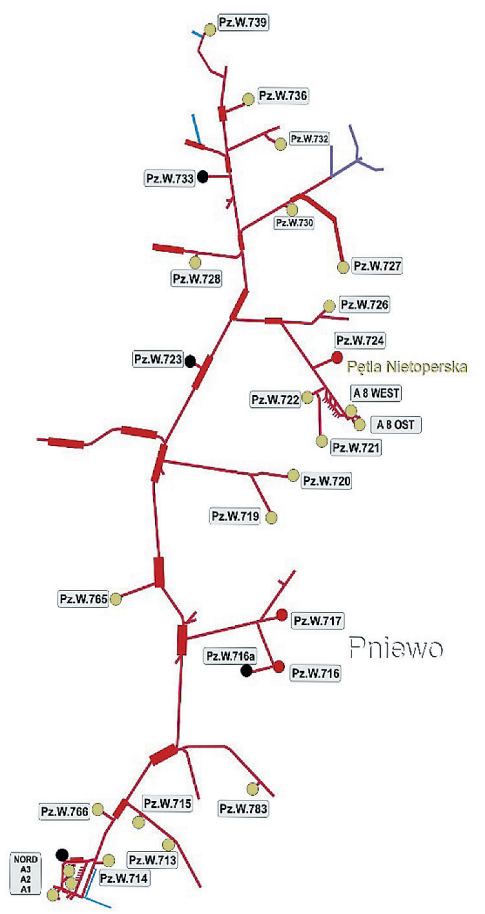

Rys. 6. Schemat istniejących bunkrów i korytarzy podziemnych MRU w pobliżu miejscowości Pniewo (schondorf.pl)

Dodatkowo wszystkie budowle były zelektryfikowane, połączone liniami telefonicznymi oraz wyposażono je w zaawansowane systemy zaopatrywania w wodę, urządzenia sanitarne a także oczyszczalnie ścieków. Niektóre bunkry zabezpieczono również przed atakiem gazowym poprzez wyposażenie w systemy wentylacyjne $\mathrm{z}$ filtrami powietrza oraz komory odkażające.

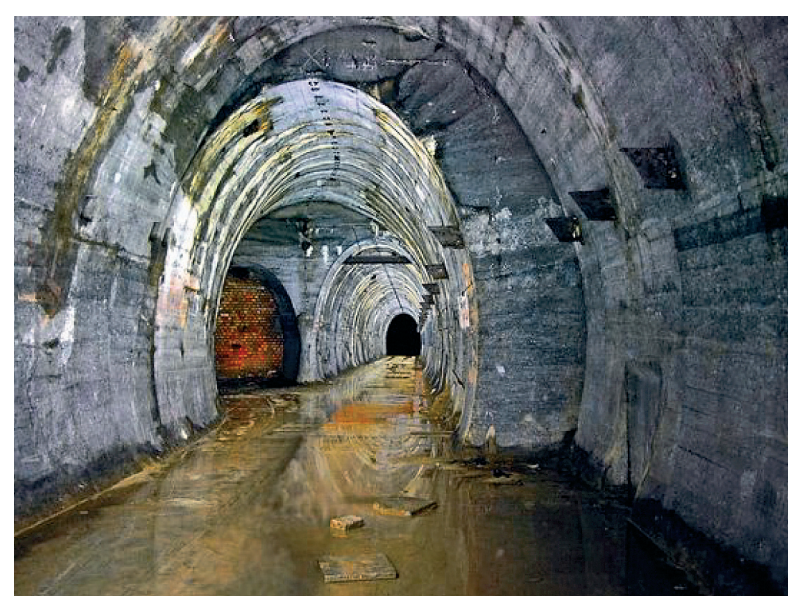

Rys. 7. Wnętrze podziemnego korytarza MRU (bank-zdjec.pl) 
Pomimo ogromnego nakładu sił i środków użytych do budowy frontu ufortyfikowanego, nigdy go nie ukończono. Cały system nie uzyskał pełnej funkcjonalności ani zdolności bojowej, był też słabo obsadzony załogą. Główny cel strategiczny, który przyświecał jego budowniczym, czyli obrona Berlina przed atakiem ze wschodu nie został osiągnięty. Zmierzająca do stolicy III Rzeszy Armia Czerwona, doświadczona w działaniach bojowych, szybko zdobyła fortyfikacje (3 dni) [1]. Największą przeszkodą, choć także do pokonania, okazało się, słusznie z założeniami niemieckich wojskowych, ukształtowanie terenu Bramy Lubuskiej. Ostatecznie Rosjanie pokonali Odrę w tym miejscu 31 stycznia 1945 roku.

\section{Użycie po II wojnie światowej}

Po zakończeniu działań wojennych fortyfikacje były przez jakiś czas okupowane przez wojska radzieckie, które wywiozły z nich całe wartościowe wyposażenie jakie udało im się znaleźć. Następnie przekazano teren Ludowemu Wojsku Polskiemu, ponieważ całość umocnień znalazła się na nowo wytyczonym obszarze Polski. LWP kilkukrotnie prowadziło analizy nad wykorzystaniem frontu, nazywanego po wojnie Międzyrzeckim Rejonem Umocnionym (MRU), w celu obrony zachodniej granicy Rzeczypospolitej, za każdym razem uznawano to jednak za bezcelowe. Ostatnia taka analiza miała miejsce w roku 1973 i dotyczyła możliwości wykorzystania fortyfikacji jako schronów podczas wojny nuklearnej. W roku 1976 wojsko nieodpłatnie przekazało cały obszar administracji cywilnej, a konkretnie Zarządowi Państwowych Gospodarstw Rolnych w Zielonej Górze i Gorzowie Wielkopolskim [3]. Przez cały okres po zakończeniu wojny schrony stopniowo niszczały, wiele z nich zostało zalanych a ich wyposażenie rozkradziono.

Kiedy obiekty opuściło w wojsko zainteresowali się nimi mieszkańcy okolicznych miejscowości oraz turyści. Koniec lat 70. i całe lata 80. ubiegłego stulecia wypełnione były ruchem turystycznym, którego nikt nie kontrolował. Doprowadziło to do ostatecznej dewastacji mienia przez ,poszukiwaczy skarbów” i eksploratorów wierzących, że odnajdą tam pozostałości historii. W roku 1985 istniały plany wykorzystania schronów i korytarzy podziemnych jako wysypiska odpadów radioaktywnych. Lata 90. obfitowały w bezskuteczne działania mające na celu skłonić władze i służby konserwatorskie do ochrony tego jedynego w swoim rodzaju systemu fortyfikacji zachowanych na terenie Polski. Efektem było jedynie wprowadzenie nadzoru nad budowlą służb zajmujących się ochroną środowiska, ze względu na znajdującą się tam kolonię nietoperzy (ok 30 tysięcy osobników). W takiej sytuacji prace związane z ochroną konserwatorską i ewentualna modernizacja zabytków architektury obronnej są mocno utrudnione, a czasem wręcz niemożliwe ze względu na ochronę zamieszkujących tam nietoperzy [1].

\section{Stan obecny oraz plany na przyszłość}

Obecnie, w najlepiej zachowanej części MRU w pobliżu miejscowości Pniewo, znajduje się Muzeum Fortyfikacji i Nietoperzy a turyści mogą zwiedzać, pod opieką przewodników część zachowanych w dobrym stanie i niezalanych schronów oraz korytarzy. Wciąż prowadzone są dyskusje nad możliwościami wykorzystania potencjału tego wyjątkowego obszaru i jego ochrony. Jedną z koncepcji jest utworzenie w Pniewie Muzeum Sztuki Wojskowej, zamiast istniejącego Muzeum Fortyfikacji i Nietoperzy. Miałyby do niego zostać przeniesione także zbiory Lubuskiego Muzeum Wojskowego w Drzonowie. Rozważana jest także 
opcja militarnego parku rozrywki, nie tylko dla turystów zainteresowanych militariami, ale także dla całych rodzin. Argumentami przemawiającymi za tymi rozwiązaniami są: bardzo dobre położenie miejscowości Pniewo przy skrzyżowaniu dwóch międzynarodowych szlaków komunikacyjnych, przebiegających przez województwo lubuskie, autostrady A2 i drogi ekspresowej S3, oraz popularność MRU nie tylko w Polsce ale także na świecie.

\title{
5. Wnioski
}

Europa ukształtowana przez stulecia wojen i konfliktów pełna jest śladów burzliwej historii. Jednym z najciekawszych miejsc związanych z II wojną światową na terenie zachodniej Polski, jest Międzyrzecki Rejon Umocniony. Budowany w latach 1928-1944 system schronów, umocnień, korytarzy podziemnych, budowli hydrotechnicznych, przepraw przez rzeki oraz infrastruktury transportowej nigdy nie został w pełni ukończony, ani nie odegrał znaczącej roli podczas obrony wschodnich granic III Rzeszy. Jego pozostałości do dziś są świadectwem kunsztu inżynierów i budowniczych i na trwałe wpisały się w krajobraz centralnej części województwa lubuskiego. Ochrona oraz wykorzystanie potencjału tego zabytku architektury obronnej powinny być ważnymi celami dla samorządu i służb konserwatorskich. Istniejące koncepcje wykorzystania obszaru i jego dalszej popularyzacji wśród turystów, takie jak Muzeum Sztuki Wojskowej czy militarny park rozrywki mogą być ciekawą drogą do realizacji tych planów.

\section{Literatura}

[1] Miniewicz J., Perzyk B. Międzyrzecki Rejon Umocniony. MBP-Militaria Bogusława Perzyka, Warszawa, 2012.

[2] Michalak R. Koleje żelazne Frontu Ufortyfikowanego Euku Odry-Warty w latach 1936-1945, [w:] Międzyrzecki Rejon Umocniony. 80 lat zabytku architektury obronnej, (ed. Urbanek G.), Muzeum Fortyfikacji i Nietoperzy w Pniewie, Pniewo, 2013.

[3] Urbanek G. Wojsko Polskie a fortyfikacje MRU w talach 70. i 80. XX w., [w:] Międzyrzecki Rejon Umocniony. 80 lat zabytku architektury obronnej, (ed. Urbanek G.), Muzeum Fortyfikacji i Nietoperzy w Pniewie, Pniewo, 2013.

\section{Międzyrzecz Fortified Region (Festungfront Oder-Warthe-Bogen) - in anticipation of adaptations and modernizations}

\author{
Bartosz Michalak
}

\begin{abstract}
Institute of Building Engineering, Faculty of Building Engineering, Architecture and Environmental Engineering, University of Zielona Góra, e-mail: b.michalak@ib.uz.zgora.pl
\end{abstract}

\begin{abstract}
Between Wrocław and Krosno Odrzańskie, in the years 1928-1944, about 650 reinforced concrete and passive bunkers were built. On a stretch of about $250 \mathrm{~km}$, both small buildings for two or three people as well as the whole underground barracks were build. In addition, concrete anti-tank barriers, dams, bridges and other concrete structures were
\end{abstract}


built. An important part of these fortifications of eastern German borders was Międzyrzecz Fortified Region, now in the Lubuskie Voivodeship. Since 1970s. , these objects do not have primary functions. However, it is still one of the largest defense systems in the world. The length of underground corridors is over $30 \mathrm{~km}$. Nature has used these rooms as a natural habitat for tens of thousands of bats over time. Unfortunately, man has no idea for a good transmutation. The use of these buildings for modern purposes will require huge financial resources but above all interesting ideas and bold projects.

The article presents the history and description of the complex as well as proposals for adapting shelters for new purposes. There are several concepts and the implementation of these plans would be a valuable initiative related to the protection of this unique area and engineering structures located there.

Keywords: fortifications, bunkers, Lubusz Gate, museum of war art, Pniewo. 